\title{
Jannaschia seohaensis sp. nov., isolated from a tidal flat sediment
}

\author{
Jung-Hoon Yoon, So-Jung Kang, Sooyeon Park, Ki-Hoon Oh \\ and Tae-Kwang Oh
}

Correspondence

Jung-Hoon Yoon

jhyoon@kribb.re.kr Korea Research Institute of Bioscience and Biotechnology (KRIBB), PO Box 115, Yusong, Taejon,
Republic of Korea
The genus Jannaschia was proposed by Wagner-Döbler et al. (2003) and, at the time of writing, the genus comprises five species with validly published names: Jannaschia helgolandensis (Wagner-Döbler et al., 2003), J. rubra (Macián et al., 2005), J. seosinensis (Choi et al., 2006), J. donghaensis (Yoon et al., 2007) and J. pohangensis (Kim et al., 2008). Jannaschia cystaugens, which had been described by Adachi et al. (2004), was reclassified as a synonym of Thalassobacter stenotrophicus by Pujalte et al. (2005). In this study, we report the taxonomic characterization of a Jannaschia-like bacterial strain, SMK-146 which was isolated from a tidal flat sediment of the Yellow Sea, Korea.

Strain SMK- $146^{\mathrm{T}}$ was isolated from a tidal flat sediment from Saemankum of the Yellow Sea, Korea, by means of the standard dilution-plating technique at $25{ }^{\circ} \mathrm{C}$ on marine agar 2216 (MA; Difco). The type strains of the five recognized Jannaschia species were used for DNA-DNA hybridization, phenotypic characterization and fatty acid analysis. J. helgolandensis DSM $14858^{\mathrm{T}}$ and J. rubra DSM $16279^{\mathrm{T}}$ were obtained from the Deutsche Sammlung von Mikroorganismen und Zellkulturen. J. seosinensis KCCM $42114^{\mathrm{T}}$ was obtained from the Korean Culture Center of

The GenBank/EMBL/DDBJ accession number for the 16S rRNA gene sequence of strain SMK-146 ${ }^{\top}$ is EU156067.

A two-dimensional TLC of polar lipids of strain SMK-146 ${ }^{\top}$ is available as supplementary material with the online version of this paper.
Microorganisms. J. pohangensis KACC $11609^{\mathrm{T}}$ was obtained from the Korean Agricultural Culture Collection. J. donghaensis DSW $-17^{\mathrm{T}}$ was obtained in the study of Yoon et al. (2007). The morphological, physiological and biochemical characteristics of strain SMK- $146^{\mathrm{T}}$ were investigated using routine cultivation on MA at $30{ }^{\circ} \mathrm{C}$. The cell morphology was examined by light microscopy (Nikon E600) and transmission electron microscopy. Flagellation was determined using a Philips CM-20 transmission electron microscope with cells from exponentially growing cultures: for this purpose, the cells were negatively stained with $1 \%(\mathrm{w} / \mathrm{v})$ phosphotungstic acid and the grids were examined after being air-dried. Growth under anaerobic conditions was determined after incubation in a Forma anaerobic chamber on MA and MA supplemented with potassium nitrate $(0.1 \%, \mathrm{w} / \mathrm{v})$, both of which had been prepared anaerobically using nitrogen. Growth in the absence of $\mathrm{NaCl}$ was investigated using trypticase soy broth (Difco) prepared according to the manufacturer's instructions except that $\mathrm{NaCl}$ was omitted. Growth at various $\mathrm{NaCl}$ concentrations $(0.5 \%$, w/v, and $1.0-12.0 \%, \mathrm{w} / \mathrm{v}$, in increments of $1.0 \%$ ) was investigated in marine broth 2216 (MB; Difco) and trypticase soy broth. Growth at various temperatures $(4,10,15,20,22,25,28$ and $30-45{ }^{\circ} \mathrm{C}$ in increments of $1.0{ }^{\circ} \mathrm{C}$ ) was measured on MA. The $\mathrm{pH}$ range and optimal $\mathrm{pH}$ for growth was determined in $\mathrm{MB}$ that was adjusted to $\mathrm{pH} 4.5-9.5$ (in increments of $0.5 \mathrm{pH}$ units) by the addition of $\mathrm{HCl}$ or 
$\mathrm{Na}_{2} \mathrm{CO}_{3}$. Catalase and oxidase activities and hydrolysis of casein, starch and Tweens 20, 40, 60 and 80 were determined as described by Cowan \& Steel (1965). Hydrolysis of hypoxanthine, tyrosine and xanthine was tested on MA, using the substrate concentrations described by Cowan \& Steel (1965). Hydrolysis of aesculin, gelatin and urea and reduction of nitrate were investigated as described by Lányí (1987) with the modification that artificial seawater was used for media preparation. The artificial seawater contained [(1 distilled water $\left.)^{-1}\right] 23.6 \mathrm{~g}$ $\mathrm{NaCl}, \quad 0.64 \mathrm{~g} \quad \mathrm{KCl}, \quad 4.53 \mathrm{~g} \quad \mathrm{MgCl}_{2} .6 \mathrm{H}_{2} \mathrm{O}, \quad 5.94 \mathrm{~g}$ $\mathrm{MgSO}_{4} \cdot 7 \mathrm{H}_{2} \mathrm{O}$ and $1.3 \mathrm{~g} \mathrm{CaCl} \cdot 2 \mathrm{H}_{2} \mathrm{O}$ (Bruns et al., 2001). $\mathrm{H}_{2} \mathrm{~S}$ production was tested as described by Bruns et al. (2001). Susceptibility to antibiotics was investigated on MA plates by using antibiotic discs containing the following ( $\mu \mathrm{g}$ unless otherwise stated): polymyxin B (100 U), streptomycin (50), penicillin G $(20 \mathrm{U})$, chloramphenicol (100), ampicillin (10), cephalothin (30), gentamicin (30), novobiocin (5), tetracycline (30), kanamycin (30), lincomycin (15), oleandomycin (15), neomycin (30) and carbenicillin (100). Acid production from carbohydrates was tested as described by Leifson (1963). Utilization of various substrates for growth was tested as described by Choi et al. (1981) with the modification that Noble agar (Difco) was used instead of Bacto agar (Difco). Carbon sources were added at a concentration of $0.2 \%$ $(\mathrm{w} / \mathrm{v})$ after sterilization by filtration. Enzyme activities were determined by using the API ZYM system (bioMérieux). For in vivo pigment-absorption spectrum analysis, strain SMK- $146^{\mathrm{T}}$ was cultivated aerobically in the dark at $30{ }^{\circ} \mathrm{C}$ in $\mathrm{MB}$. The pigment absorption spectrum was analysed as described by Rainey et al. (2003). The culture was washed twice by centrifugation with a MOPS buffer $(0.01 \mathrm{M}$ MOPS/NaOH, 0.1 M KCl, $\left.0.001 \mathrm{M} \mathrm{MgCl}_{2}, \mathrm{pH} 7.5\right)$ and disrupted by sonication with a Branson Sonifier 450. After removal of cell debris by centrifugation, the absorption spectrum of the supernatant was examined on a Beckman Coulter DU800 spectrophotometer.

Cell biomass for DNA extraction and for the analyses of isoprenoid quinones and polar lipids was obtained from cultures grown in $\mathrm{MB}$ at $30{ }^{\circ} \mathrm{C}$. Chromosomal DNA was isolated and purified according to the method described by Yoon et al. (1996), with the exception that RNase T1 was used in combination with RNase A to minimize contamination by RNA. The $16 \mathrm{~S}$ rRNA gene sequence was amplified by PCR using two universal primers, $5^{\prime}$ -

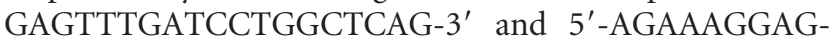
GTGATCCAGCC-3', as described previously (Yoon et al., 1998). Sequencing and phylogenetic analysis were performed as described previously (Yoon et al., 2003). Isoprenoid quinones were analysed as described by Komagata \& Suzuki (1987) using reversed-phase HPLC. Polar lipids were extracted according to the procedures described by Minnikin et al. (1984) and identified by twodimensional TLC followed by spraying with appropriate detection reagents (Minnikin et al., 1984; Komagata \& Suzuki, 1987). The presence of phosphatidylcholine was determined with Dragendorff's reagent (Sigma). For cellular fatty acid analysis, cell biomass was harvested from MA plates after cultivation for 7 days at $30{ }^{\circ} \mathrm{C}$ except for $J$. donghaensis DSW $-17^{\mathrm{T}}$, which was harvested from MA plates after cultivation for 7 days at $25{ }^{\circ} \mathrm{C}$. The fatty acids were extracted and fatty acid methyl esters were prepared according to the standard protocol of the MIDI/Hewlett Packard Microbial Identification System (Sasser, 1990). The DNA G + C content was determined by the method of Tamaoka \& Komagata (1984) with a modification that DNA was hydrolysed using nuclease P1 (Sigma) and the resultant nucleotides were analysed by reversed-phase HPLC. DNA-DNA hybridization was performed fluorometrically by the method of Ezaki et al. (1989) using photobiotin-labelled DNA probes for cross-hybridization in microdilution wells. Hybridization was performed with five replications for each sample. The highest and lowest values obtained in each sample were excluded and the means of the remaining three values are quoted as DNADNA relatedness values.

Morphological, cultural, physiological and biochemical characteristics of strain SMK-146 ${ }^{\mathrm{T}}$ are given in the species description and in Table 1. Sonicated cell extracts of strain SMK-146 ${ }^{\mathrm{T}}$ showed absorption maxima at 406 and $864 \mathrm{~nm}$. Acetone/methanol extracts had maximal absorption peaks at 414,678 and $751-752 \mathrm{~nm}$. These data indicated the presence of carotenoids and bacteriochlorophyll $a$ in strain SMK-146 ${ }^{\mathrm{T}}$. The almost-complete $16 \mathrm{~S}$ rRNA gene sequence of strain SMK-146 ${ }^{\mathrm{T}}$ determined in this study comprised $1418 \mathrm{nt}$, which represents approximately $96 \%$ of the Escherichia coli $16 \mathrm{~S}$ rRNA gene sequence. In the phylogenetic tree based on the neighbour-joining algorithm, strain SMK-146 ${ }^{\mathrm{T}}$ fell within the clade comprising Jannaschia species and clustered with $J$. seosinensis CL-SP26 ${ }^{\mathrm{T}}$ with a bootstrap resampling value of $80.7 \%$ (Fig. 1). The relationship between SMK-146 ${ }^{\mathrm{T}}$ and J. seosinensis CL$\mathrm{SP} 26^{\mathrm{T}}$ was also recovered in trees based on the maximumlikelihood and maximum-parsimony algorithms (Fig. 1). Strain SMK-146 ${ }^{\mathrm{T}}$ exhibited 16S rRNA gene sequence similarity of $97.0 \%$ to J. seosinensis CL-SP26 ${ }^{\mathrm{T}}$, 95.3$96.7 \%$ to the type strains of the other Jannaschia species and less than $94.6 \%$ to the other species used in the phylogenetic analysis. The predominant ubiquinone detected in strain SMK-146 ${ }^{\mathrm{T}}$ was Q-10 (peak area ratio approximately $95 \%$ ). The major polar lipids found in strain SMK- $146^{\mathrm{T}}$ were phosphatidylcholine, phosphatidylglycerol and phosphatidylethanolamine; minor amounts of unidentified phospholipids and lipids were also present (Supplementary Fig. S1, available in IJSEM Online). The polar lipid profile of SMK- $146^{\mathrm{T}}$ was distinguishable from the profile of $J$. helgolandensis in that diphosphatidylglycerol and an aminolipid are absent and from the profile of J. donghaensis in that an unidentified glycolipid is absent (Wagner-Döbler et al., 2003; Yoon et al., 2007). The fatty acid profile of strain SMK- $146^{\mathrm{T}}$ and those of the type strains of the Jannaschia species analysed in this study are shown in Table 2. The major components $(>10 \%$ of total 
Table 1. Differential phenotypic characteristics of strain SMK $-146^{\top}$ (Jannaschia seohaensis sp. nov.) and Jannaschia species

Species: 1, J. seohaensis sp. nov. SMK-146 ${ }^{\mathrm{T}}$ (data from this study); 2, J. helgolandensis (Wagner-Döbler et al., 2003; Choi et al., 2006); 3, J. rubra (Macián et al., 2005; Choi et al., 2006); 4, J. seosinensis (Choi et al., 2006); 5, J. donghaensis (Yoon et al., 2007); 6, J. pohangensis (Kim et al., 2008). In addition to the sources given, data for carbon source utilization, oxidase activity, antibiotic susceptibility, gelatin and starch hydrolysis, colony colour and reduction of nitrate for the type strains of all of the Jannaschia species were taken from this study. All species are positive for utilization of D-glucose, D-fructose, D-galactose, cellobiose, D-xylose and acetate, activity of catalase, oxidase, alkaline phosphatase, esterase (C4) and leucine arylamidase and susceptibility to carbenicillin, cephalothin, chloramphenicol, gentamicin, kanamycin, neomycin, novobiocin, penicillin G, polymyxin B and streptomycin. All species are negative for Gram-staining, hydrolysis of gelatin and starch, utilization of benzoate, formate and salicin, activity of lipase (C14), cystine arylamidase, trypsin, $\alpha$-chymotrypsin, $\beta$-glucuronidase, $\beta$-glucosidase, $N$-acetyl- $\beta$-glucosaminidase, $\alpha$-mannosidase and $\alpha$-fucosidase and susceptibility to lincomycin. + , Positive; w, weakly positive; - , negative.

\begin{tabular}{|c|c|c|c|c|c|c|}
\hline Characteristic & 1 & 2 & 3 & 4 & 5 & 6 \\
\hline \multicolumn{7}{|l|}{ Cell characteristics } \\
\hline Shape & Pleomorphic & Irregular rods & Rods & Rods & Pleomorphic & Rods \\
\hline Diameter $(\mu \mathrm{m})$ & $0.5-1.5$ & $0.7-1.1$ & 0.5 & $0.7-1.2$ & $0.5-2.5$ & $0.7-1.0$ \\
\hline Motility & + & - & + & + & - & + \\
\hline Colony colour (MA) & $\begin{array}{l}\text { Light orange or } \\
\text { cream* }^{*}\end{array}$ & Pale yellow & Moderate orange & Strong orange & Strong orange & Pale yellow \\
\hline \multicolumn{7}{|l|}{ Temperature for growth } \\
\hline Maximum $\left({ }^{\circ} \mathrm{C}\right)$ & 43 & 30 & 25 & 35 & 32 & 35 \\
\hline Optimum $\left({ }^{\circ} \mathrm{C}\right)$ & 30 & $25-30$ & $20-25$ & $30-35$ & 25 & 30 \\
\hline Nitrate reduction to nitrite & + & - & + & - & - & - \\
\hline \multicolumn{7}{|l|}{ Hydrolysis of: } \\
\hline Aesculin & $\mathrm{W}$ & - & - & $\mathrm{W}$ & - & - \\
\hline Maltose & - & - & - & - & + & - \\
\hline D-Mannose & + & + & + & + & + & - \\
\hline Sucrose & + & - & - & + & + & - \\
\hline Trehalose & $\mathrm{w}$ & - & - & - & - & - \\
\hline Citrate & - & + & + & - & - & - \\
\hline L-Glutamate & - & + & + & + & - & $\mathrm{w}$ \\
\hline Pyruvate & - & $\mathrm{w}$ & + & - & $\mathrm{w}$ & + \\
\hline Succinate & + & + & + & + & - & + \\
\hline \multicolumn{7}{|l|}{ Enzyme activity (API ZYM) $\dagger$} \\
\hline Esterase lipase (C8) & + & $\mathrm{W}$ & $\mathrm{w}$ & + & + & + \\
\hline Acid phosphatase & - & $\mathrm{w}$ & + & - & + & + \\
\hline Oleandomycin & + & - & - & + & - & $\mathrm{w}$ \\
\hline Tetracycline & - & + & - & - & + & - \\
\hline DNA G $+\mathrm{C}$ content $(\mathrm{mol} \%)$ & 68.4 & $63.0-63.1$ & 64.6 & 63 & 65.2 & 63.6 \\
\hline
\end{tabular}

${ }^{\star}$ Light orange at 25 and $30{ }^{\circ} \mathrm{C}$, but cream at $37^{\circ} \mathrm{C}$.

$\dagger$ Data for J. helgolandensis and J. rubra were taken from Choi et al. (2006).

fatty acids) were $\mathrm{C}_{18: 1} \omega 7 c(59.3 \%)$ and 11-methyl $\mathrm{C}_{18: 1} \omega 7 c(23.7 \%)$. This fatty acid profile was similar to those of Jannaschia species, although there were differences in the proportions of some fatty acids, particularly 11- methyl $\mathrm{C}_{18: 1} \omega 7 c$ and cyclo $\mathrm{C}_{19: 0} \omega 8 c$, between strain SMK$146^{\mathrm{T}}$ and the type strains of Jannaschia species (Table 2). The DNA G+C content of strain SMK-146 ${ }^{\mathrm{T}}$ was $68.4 \mathrm{~mol} \%$, which is higher than those of the other 


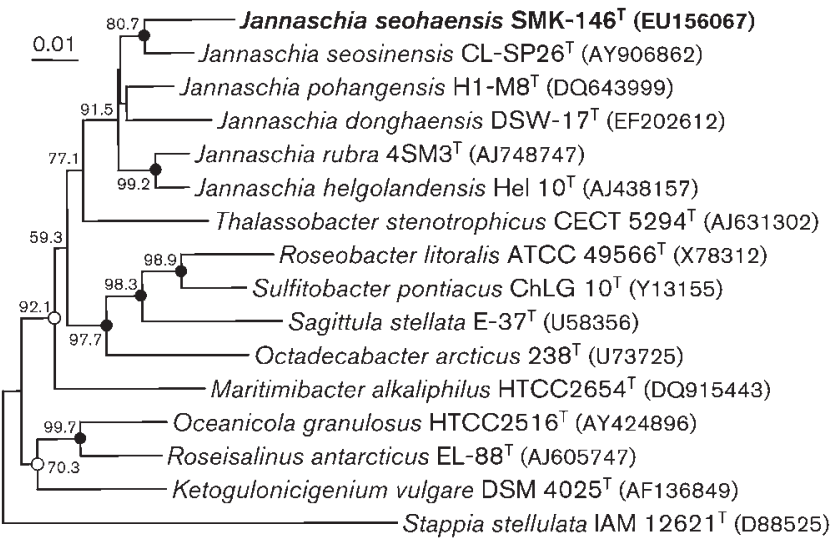

Fig. 1. Neighbour-joining phylogenetic tree based on $16 \mathrm{~S}$ rRNA gene sequences showing the relative positions of strain SMK$146^{\top}$ (Jannaschia seohaensis sp. nov.), Jannaschia species and some other related taxa. Bootstrap values ( $>50 \%$ ) based on 1000 replications are shown at branch nodes. Filled circles indicate that the corresponding nodes were also recovered in maximumlikelihood and maximum-parsimony trees. Open circles indicate that the corresponding nodes were also recovered in either the maximum-likelihood or the maximum-parsimony tree. The sequence of Stappia stellulata IAM $12621^{\top}$ was used as an outgroup. Bar, 0.01 substitutions per nucleotide position.

Jannaschia species. The results obtained from chemotaxonomic analyses supports the result of the phylogenetic analysis based on 16S rRNA gene sequences. Accordingly, it was concluded that strain SMK-146 ${ }^{\mathrm{T}}$ is a member of the genus Jannaschia.

The mean DNA-DNA relatedness value between strain SMK-146 ${ }^{\mathrm{T}}$ and J. seosinensis KCCM $42114^{\mathrm{T}}$ was $17 \%$, which indicates that strain SMK-146 ${ }^{\mathrm{T}}$ represents a genomic species that is distinct from J. seosinensis (Wayne et al., 1987). Strain SMK-146 ${ }^{\mathrm{T}}$ was distinguishable from recognized Jannaschia species through differences in several phenotypic characteristics and in the proportions of some fatty acids, particularly 11-methyl $\mathrm{C}_{18: 1} \omega 7 c$ (Tables 1 and 2 ). The phylogenetic distinctiveness, together with the genetic distinctiveness and differential phenotypic properties, is sufficient to show that strain SMK-146 ${ }^{\mathrm{T}}$ is separate from recognized Jannaschia species (Wayne et al., 1987; Stackebrandt \& Goebel, 1994). On the basis of the data presented, strain SMK-146 ${ }^{\mathrm{T}}$ represents a novel species within the genus Jannaschia, for which the name Jannaschia seohaensis sp. nov. is proposed.

\section{Description of Jannaschia seohaensis sp. nov.}

Jannaschia seohaensis (seo.ha.en'sis. N.L. fem. adj. seohaensis of Seohae, the Korean name of the Yellow Sea of Korea, from where the type strain was isolated).

Cells are Gram-staining-negative and rod-, oval- or coccoid-shaped $(0.5-1.5 \times 0.5-3.5 \mu \mathrm{m})$. Motile by means
Table 2. Cellular fatty acid compositions of $J$. seohaensis sp. nov. SMK $-146^{\top}$ and the type strains of Jannaschia species

Strains: 1, J. seohaensis sp. nov. SMK-146 ${ }^{\mathrm{T}}$; 2, J. helgolandensis DSM $14858^{\mathrm{T}}$; 3, J. rubra DSM $16279^{\mathrm{T}}$; 4, J. seosinensis KCCM 42114 ${ }^{\mathrm{T}}$; 5, J. donghaensis DSW-17 $; 7^{\mathrm{T}} ; 6$, J. pohangensis KACC $11609^{\mathrm{T}}$. All data were taken from this study. Values are percentages of total fatty acids; fatty acids that represented $<0.5 \%$ in all strains are omitted. - , Not detected.

\begin{tabular}{|c|c|c|c|c|c|c|}
\hline Fatty acid & 1 & 2 & 3 & 4 & 5 & 6 \\
\hline \multicolumn{7}{|l|}{ Straight-chain } \\
\hline $\mathrm{C}_{12: 0}$ & 0.6 & - & 0.2 & - & - & - \\
\hline $\mathrm{C}_{16: 0}$ & 0.8 & 0.4 & 0.9 & 2.2 & 0.4 & 0.8 \\
\hline $\mathrm{C}_{17: 0}$ & 1.0 & 2.8 & 0.3 & 2.2 & 1.2 & 1.3 \\
\hline $\mathrm{C}_{18: 0}$ & 5.9 & 11.1 & 9.6 & 10.3 & 5.5 & 9.4 \\
\hline $\mathrm{C}_{19: 0}$ & 0.4 & 2.1 & - & 0.5 & 2.9 & 1.1 \\
\hline \multicolumn{7}{|l|}{ Unsaturated } \\
\hline $\mathrm{C}_{18: 1} \omega 7 c$ & 60.7 & 21.2 & 48.8 & 72.6 & 71.4 & 51.8 \\
\hline $\mathrm{C}_{20: 1} \omega 7 c$ & 0.7 & 0.3 & 0.4 & 0.5 & 2.8 & 0.6 \\
\hline \multicolumn{7}{|l|}{ Hydroxy } \\
\hline $\mathrm{C}_{10: 0} 3-\mathrm{OH}$ & 1.4 & 2.9 & 2.7 & 2.7 & 2.0 & 3.9 \\
\hline $\begin{array}{l}\text { 11-Methyl } \\
\mathrm{C}_{18: 1} \omega 7 c\end{array}$ & 23.0 & 6.9 & 1.8 & - & 6.1 & 23.8 \\
\hline 10-Methyl $C_{19: 0}$ & - & - & - & 1.7 & - & - \\
\hline $\begin{array}{l}\text { Cyclo } C_{19: 0} \omega 8 c \\
\text { Summed feature }\end{array}$ & - & 42.6 & 31.0 & - & - & - \\
\hline 2 & 0.3 & 2.0 & 0.8 & 2.2 & - & - \\
\hline 3 & 0.5 & - & 0.3 & 1.1 & 0.3 & - \\
\hline 7 & 1.1 & 2.8 & - & - & 3.5 & 2.3 \\
\hline $\begin{array}{l}\text { Unknown ECL } \\
11.799\end{array}$ & 3.7 & 4.2 & 3.0 & 3.4 & 2.5 & 5.0 \\
\hline
\end{tabular}

* Summed features represent two or three fatty acids that cannot be separated by the Microbial Identification System. Summed feature 2 consisted of iso- $\mathrm{C}_{16: 1}$ and/or $\mathrm{C}_{14: 0}$ 3-OH. Summed feature 3 consisted of $\mathrm{C}_{16: 1} \omega 7 c$ and/or iso- $\mathrm{C}_{15: 0}$ 2-OH. Summed feature 7 consisted of one or more of $\mathrm{C}_{19: 1} \omega 6 c$, cyclo $\mathrm{C}_{19: 0} \omega 10 c$ and an unknown fatty acid (ECL 18.846).

of one or more polar flagella. Colonies on MA are circular, slightly convex, glistening, smooth and $1.5-2.0 \mathrm{~mm}$ in diameter after 7 days' incubation at $30{ }^{\circ} \mathrm{C}$. Colonies are light orange in colour at 25 and $30^{\circ} \mathrm{C}$, but cream-coloured at $37{ }^{\circ} \mathrm{C}$. Growth occurs at 4 (weak) and $43{ }^{\circ} \mathrm{C}$ (optimum $30{ }^{\circ} \mathrm{C}$ ) but not at $44{ }^{\circ} \mathrm{C}$, at $\mathrm{pH} 5.5$ (optimum $\mathrm{pH} 7.0-8.0$ ) but not at pH 5.0 and with $9 \%(\mathrm{w} / \mathrm{v}) \mathrm{NaCl}$ but not with $0 \%$ or more than $10 \%(\mathrm{w} / \mathrm{v}) \mathrm{NaCl}$. Anaerobic growth does not occur on MA or on MA supplemented with nitrate. Bacteriochlorophyll $a$ and carotenoids are produced. Casein, hypoxanthine, L-tyrosine and Tweens 20, 40 and 60 are hydrolysed, but xanthine is not. $\mathrm{H}_{2} \mathrm{~S}$ is not produced. L-Arabinose is utilized, but maltose, benzoate, formate, salicin and L-glutamate are not. Susceptible to ampicillin, carbenicillin, cephalothin, chloramphenicol, gentamicin, kanamycin, neomycin, novobiocin, oleandomycin, penicillin $G$, polymyxin $B$ and streptomycin, but not to tetracycline or lincomycin. The predominant 
ubiquinone is Q-10. The major fatty acids ( $>10 \%$ of total fatty acids) are $\mathrm{C}_{18: 1} \omega 7 c$ and 11-methyl $\mathrm{C}_{18: 1} \omega 7 c$. The major polar lipids are phosphatidylcholine, phosphatidylglycerol and phosphatidylethanolamine. Other phenotypic characteristics are given in Table 1. The DNA G+C content of the type strain is $68.4 \mathrm{~mol} \%$ (HPLC).

The type strain, SMK-146 ${ }^{\mathrm{T}}\left(=\right.$ KCTC $22172^{\mathrm{T}}=$ CCUG $55326^{\mathrm{T}}$ ), was isolated from a tidal flat sediment of the Yellow Sea, Saemankum, Korea.

\section{Acknowledgements}

This work was supported by the 21C Frontier program of Microbial Genomics and Applications (grant MG05-0401-2-0) from the Ministry of Science and Technology (MOST) of the Republic of Korea.

\section{References}

Adachi, M., Kanno, T., Okamoto, R., Shinozaki, A., Fujikawa-Adachi, K. \& Nishijima, T. (2004). Jannaschia cystaugens sp. nov., an Alexandrium (Dinophyceae) cyst formation-promoting bacterium from Hiroshima Bay, Japan. Int J Syst Evol Microbiol 54, 1687-1692.

Baumann, P. \& Baumann, L. (1981). The marine Gram-negative eubacteria: genera Photobacterium, Beneckea, Alteromonas, Pseudomonas, and Alcaligenes. In The Prokaryotes, pp. 1302-1331. Edited by M. P. Starr, H. Stolp, H. G. Trüper, A. Balows \& H. G. Schlegel. Berlin: Springer.

Bruns, A., Rohde, M. \& Berthe-Corti, L. (2001). Muricauda ruestringensis gen. nov., sp. nov., a facultatively anaerobic, appendaged bacterium from German North Sea intertidal sediment. Int $J$ Syst Evol Microbiol 51, 1997-2006.

Choi, D. H., Yi, H., Chun, J. \& Cho, B. C. (2006). Jannaschia seosinensis sp. nov., isolated from hypersaline water of a solar saltern in Korea. Int J Syst Evol Microbiol 56, 45-49.

Cowan, S. T. \& Steel, K. J. (1965). Manual for the Identification of Medical Bacteria. London: Cambridge University Press.

Ezaki, T., Hashimoto, Y. \& Yabuuchi, E. (1989). Fluorometric deoxyribonucleic acid-deoxyribonucleic acid hybridization in microdilution wells as an alternative to membrane filter hybridization in which radioisotopes are used to determine genetic relatedness among bacterial strains. Int J Syst Bacteriol 39, 224-229.

Kim, B.-Y., Yoo, S.-H., Weon, H.-Y., Jeon, Y.-A., Hong, S.-B., Go, S.-J., Stackebrandt, E. \& Kwon, S.-W. (2008). Jannaschia pohangensis sp. nov., isolated from seashore sand in Korea. Int J Syst Evol Microbiol 58, 496-499.

Komagata, K. \& Suzuki, K. (1987). Lipid and cell-wall analysis in bacterial systematics. Methods Microbiol 19, 161-207.

Lányí, B. (1987). Classical and rapid identification methods for medically important bacteria. Methods Microbiol 19, 1-67.
Leifson, E. (1963). Determination of carbohydrate metabolism of marine bacteria. J Bacteriol 85, 1183-1184.

Macián, M. C., Arahal, D. R., Garay, E., Ludwig, W., Schleifer, K. H. \& Pujalte, M. J. (2005). Jannaschia rubra sp. nov., a red-pigmented bacterium isolated from sea water. Int J Syst Evol Microbiol 55, 649653.

Minnikin, D. E., O'Donnell, A. G., Goodfellow, M., Alderson, G., Athalye, M., Schaal, A. \& Parlett, J. H. (1984). An integrated procedure for the extraction of bacterial isoprenoid quinones and polar lipids. J Microbiol Methods 2, 233-241.

Pujalte, M. J., Macián, M. C., Arahal, D. R. \& Garay, E. (2005). Thalassobacter stenotrophicus Macián et al. 2005 is a later synonym of Jannaschia cystaugens Adachi et al. 2004, with emended description of the genus Thalassobacter. Int J Syst Evol Microbiol 55, 1959-1963.

Rainey, F. A., Silva, J., Nobre, M. F., Silva, M. T. \& da Costa, M. S. (2003). Porphyrobacter cryptus sp. nov., a novel slightly thermophilic, aerobic, bacteriochlorophyll $a$-containing species. Int $J$ Syst Evol Microbiol 53, 35-41.

Sasser, M. (1990). Identification of bacteria by gas chromatography of cellular fatty acids, MIDI Technical Note 101. Newark, DE: MIDI Inc.

Stackebrandt, E. \& Goebel, B. M. (1994). Taxonomic note: a place for DNA-DNA reassociation and 16S rRNA sequence analysis in the present species definition in bacteriology. Int J Syst Bacteriol 44, 846849.

Tamaoka, J. \& Komagata, K. (1984). Determination of DNA base composition by reversed-phase high-performance liquid chromatography. FEMS Microbiol Lett 25, 125-128.

Wagner-Döbler, I., Rheims, H., Felske, A., Pukall, R. \& Tindall, B. J. (2003). Jannaschia helgolandensis gen. nov., sp. nov., a novel abundant member of the marine Roseobacter clade from the North Sea. Int J Syst Evol Microbiol 53, 731-738.

Wayne, L. G., Brenner, D. J., Colwell, R. R., Grimont, P. A. D., Kandler, O., Krichevsky, M. I., Moore, L. H., Moore, W. E. C., Murray, R. G. E. \& other authors (1987). International Committee on Systematic Bacteriology. Report of the ad hoc committee on reconciliation of approaches to bacterial systematics. Int J Syst Bacteriol 37, 463-464.

Yoon, J.-H., Kim, H., Kim, S.-B., Kim, H.-J., Kim, W. Y., Lee, S. T., Goodfellow, M. \& Park, Y.-H. (1996). Identification of Saccharomonospora strains by the use of genomic DNA fragments and rRNA gene probes. Int J Syst Bacteriol 46, 502-505.

Yoon, J.-H., Lee, S. T. \& Park, Y.-H. (1998). Inter- and intraspecific phylogenetic analysis of the genus Nocardioides and related taxa based on 16S rRNA gene sequences. Int J Syst Bacteriol 48, 187-194.

Yoon, J.-H., Kang, K. H. \& Park, Y.-H. (2003). Psychrobacter jeotgali sp. nov., isolated from jeotgal, a traditional Korean fermented seafood. Int J Syst Evol Microbiol 53, 449-454.

Yoon, J.-H., Kang, S.-J., Park, S. \& Oh, T.-K. (2007). Jannaschia donghaensis sp. nov., isolated from seawater of the East Sea, Korea. Int J Syst Evol Microbiol 57, 2132-2136. 